\title{
HISTORIC MOLDOVA. HISTORICAL DISPARITIES, REGIONALISATION AND CROSS-BORDER INTEGRATION
}

\author{
Cristian Ploscaru, ${ }^{1}$ Ionut Nistor ${ }^{2}$
}

\begin{abstract}
This study proposes a theoretical approach to the idea of a platform for research and education on the historical substance of regionalization in Romania, with reference to the case of the historical province of Moldova. Furthermore, to identify the consequences, reactions, weaknesses, opportunities afforded by administrative restructuring from a postregionalization demographic and socioeconomic viewpoint. An inter-disciplinary analysis - historical, demographic, economic - the traits of a Romanian society stemming from Moldova, the historical dynamics that underpin the modern Romanian state, will provide a picture of the current situation, focused mainly on its causes while trying to find explanations rooted in economic and social behaviours and attitudes which came to define and inform the subsequent development strategy of regionalization, allowing Moldova to play a central economic role in relation to other territories, similar to the role it played in the past two centuries, in the context of European integration strategies, in neighbouring parts of the continent (Republic of Moldova, Ukraine). The theoretical approach involves three components, expanding concentrically: 1) component of knowledge / research; 2) digital platform; 3) e-learning component. The research component seeks dynamic historical development of Moldova, from the time after the Union of the Romanian Principalities until today, focusing on specific regional elements. We will try to identify and analyze the specific features of Moldova, links with other areas of historical Moldavia, as the interaction between them and the Romanian public policy. Within the demographic component, we look at the historical population dynamics of Moldova, including various ethnic and religious communities, rural-urban ratios, social and professional structures. Another issue concerns the economic and comparative analysis in space and time, with respect to Moldova historical economic dynamics parameters - resources, infrastructure, industry, agriculture, trade, transport, etc. Both aspects will be analyzed in correlation with the impact of a permanent political factor, pursuing public policies promoted by the political regimes in their chronological sequence.
\end{abstract}

UDC Classification: 94(4/9); DOI: http://dx.doi.org/10.12955/cbup.v5.1112

Keywords: historical disparities, regionalization, development, diversity, integration

\section{Introduction}

Our paper, Historic Moldova. Historical Disparities, Regionalisation, and Cross-Border Integration, addresses a topical theme. Our intention is to suggest some directions for research and application of the results in the educational process of our University, integrating other research results into a common platform, accessible to those are interested. Throughout its construction, it will incorporate strong practical objectives. We provide the development of integrated, interdisciplinary research, providing specialist support for the impact of regionalization of Moldova. Furthermore, to identify the consequences, reactions, weaknesses, and opportunities afforded by administrative restructuring from a post-regionalization demographic and socioeconomic viewpoint. An inter-disciplinary analysis historical, demographic, economic - the traits of a Romanian society stemming from Moldova, the historical dynamics that underpin the modern Romanian state, will provide a picture of the current situation, focused mainly on its causes while trying to find explanations rooted in economic and social behaviours and attitudes which came to define and inform the subsequent development strategy of regionalization, allowing Moldova to play a central economic role in relation to other territories, similar to the role it played in the past two centuries, in the context of European integration strategies, in neighbouring parts of the continent (Republic of Moldova, Ukraine).

The theoretical approach involves three components, expanding concentrically: 1) component of knowledge / research; 2) digital platform; 3) e-learning component. The research component seeks dynamic historical development of Moldova, from the time after the Union of the Romanian Principalities until today, focusing on specific regional elements. We will try to identify and analyze the specific features of Moldova, links with other areas of historical Moldavia, as the interaction between them and the Romanian public policy. Within the demographic component, we look at the historical population dynamics of Moldova, including various ethnic and religious communities, ruralurban ratios, social and professional structures. Another issue concerns the economic and comparative analysis in space and time, with respect to Moldova historical economic dynamics parameters resources, infrastructure, industry, agriculture, trade, transport, etc. Both aspects will be analyzed in

\footnotetext{
${ }^{1}$ Associate Professor, „Alexandru Ioan Cuza” University, Iași, Romania, cploscaru@yahoo.com

${ }^{2}$ Associate Professor, „Alexandru Ioan Cuza” University, Iași, Romania, inistor2001 @ yahoo.com
} 
correlation with the impact of a permanent political factor, pursuing public policies promoted by the political regimes in their chronological sequence.

Results of the specialized research will be posted on an electronic platform. It will include extensive statistics, demographic and economic graphs and tables that can be accessed and permanently completed by other researchers. The platform will include a forum for discussion in real time, which can be used for organizing workshops, conferences or universities. It allows users to watch not only data (numbers, statistics), but also the performance, according to their own interests, graphs, tables and charts using available infrastructure information. One objective is to achieve interactive digital maps of historical Moldavia, loaded with all collected data and can be accessed for the purposes of space and time comparisons. The platform will host a photo library, a corpus documents, and a bibliography. All information will serve as a basis of support for students and will be used in seminars and supplementary courses, and for the general interest to the public at large.

\section{Methodological observations and historiographical comments}

Western research devoted to regional differences in demographic, socio-economic and habitat have a long tradition, their results are used by central governments of the states, and by managers of older or newer companies. We will report on the latest works and initiatives that provide context to our project. In 2008, a report was published by the Center for the Study of Demographic Change in Rostock (Tivig, Frosch, Kühntopf, 2008, 32) trying to conceptualize and quantify regional changes of the population during 1990-2030 and the risks involved for companies operating in the European Union. There existed major interest, not only from researchers but also from national and European political structures for finding solutions to global challenges and this found expression in the creation of the ESPON 2013 Programme - European observation network on territorial development and cohesion. The program is funded by the European Regional Development Fund, and the purpose is to support development and cohesion policy designed by utilizing: available information, statistics, analyzes and scenarios on territorial dynamics, revealing territorial capital and development potential of regions and larger territories. Under the program, Corrado Bonifazi and Massimiliano Crisci drafted a paper (Bonifazi, Crisci, 2013, 230) whose objectives were to analyze the interaction between the factors of migration, demographic and economic in the last decade in Catalonia, by which to anticipate future interactions, depending on the results of regional projects implemented by EU countries. Study of The Relationship Between Demographic Change and Economic Growth in the EU conducted in 2007 by Prskawetz Alexia, Thomas Fent, Werner Barthel (from Vienna Institute of Demography, Austrian Academy of Sciences), Jesus Crespo-Cuaresma (Department of Economics, University of Innsbruck), Thomas Lindh, Bo Malmberg, Max Halvarsson (Institute for Futures Studies, Stockholm) provides a review of recent literature linking demographic structure growth. Based on data available for the EU in 1950 to 2005, the study is a prospective analysis of future implications of demographic change on economic growth in 2050 . The document stresses that demographics may affect productivity through its impact on the economy, investments, human capital formation, technological change, etc., as the economic behavior of people and their needs vary at different stages of life, and changes in the age structure of a country may have significant effects on its economic performance.

Our research uses as point of reference the study The Role of Regional Competition for Demography and Regional Disparities in Germany, published by Florian W. Bartholomae and Alina M. Popescu of the University of the Federal Armed Forces Munich, in which they analyse the regional differences specifically between east and west and the northern and southern regions of West Germany, based on indicators such as natural population growth, fertility rates, migration, etc. Their findings show that demographic aging and population decline have serious consequences for the economic and social development of the country (Bartholomae, Popescu, 2007, 47).

In the United States, there are a number of institutes specially constituted to analyze socio-economic and demographic indicators. Institute for Research on Poverty, University of Wisconsin has developed a database to serve the general public, they store information about the local database, available online for the Midwest region. They include sites containing local statistics and a number of issues related to poverty: basic demographic information, employment, and income, health and mortality, social assistance programs. University of Texas and the Brookings Institution have collaborated to produce a website dedicated to urban poverty, which allows users to visualize poor areas of cities, determined by data provided by the censuses of 1970-2000 and know the economic development of these areas. 
Office analysis of economic and social trends of the Iowa State University, collects, analyzes, interprets and disseminates information on social trends, economic and demographic. They created a well-organized site level data for states in the Midwest region.

In our approach, we start with the idea that Romanian regionalization should not widen economic disparities. Social frustrations exist in Moldova and are noticeably reviving in the form of historical justification, particularly in the intellectual and political arena, and more importantly, manifesting in the form of competition for access to scarce resources among sub-regions and counties (Suceava, Neamţ, Bacău, Iaşi, Galaţi). An inter-disciplinary analysis - historical, demographic, economic - the traits of a Romanian society stemming from Moldova, the historical dynamics that underpin the modern Romanian state, will provide a picture of the current situation, focused mainly on its causes while trying to find explanations rooted in economic and social behaviours and attitudes which came to define and inform the subsequent development strategy of regionalization, allowing Moldova to play a central economic role in relation to other territories, similar to the role it played in the past two centuries, in the context of European integration strategies, in neighbouring parts of the continent (Republic of Moldova, Ukraine).

Also, our research and documentary support complex developed from it, will continuously refer to the concept of territorial cohesion, European and national policies essential for regional development that aim at unlocking the potential of regional and territorial capital, in consonance with shared borders, to be seen as opportunities for development, all the while increasing cultural exchanges with neighbouring states. In this regard, the European program INTERREG supported by EPSON, attaches high priority to remote regions in close proximity to borders to other countries, thus affording the Moldovian Republic a unique privilege from both points of view (Scholich, 2007, 2). One of the most challenging and difficult issues related to the concept of territorial cohesion is the related concept of territorial capital, the description, and analysis of which is a central tenet of research. This concept was defined in Territorial Outlook by OECD (2001) on four levels: 1) capital infrastructure and housing; 2) knowledge capital; 3) cultural capital and identity 4) social capital all of which will be approached from a historical perspective, with particular attention being paid to demographic- and economic factors (OECD, 2001, 15). With the some importance are level of education, including literacy, access to various educational stages, the share of specialized elites and orientation, both at the sub-regional level and in terms of ethno-religious communities, historic landmarks and cultural dynamics of identity, their size measurable quantity - Romanian, Russian, Ruthenian and Ukrainian literature etc., media, associations and cultural organizations representing civil society, birth, death, infant mortality, population movements within and outside Moldova historic urban-rural ratio horizon and comparative urbanization policies and their impact etc. Thus, the current territorial capital can be better assessed by reference to its historical foundations, not just theoretical models, often contradicted by reality.

Research undertaken within the project includes both a theoretical component, about the new lines of research in the field, whose findings should be a specific theme and a practical component, the availability of research results, not only for academics but also more especially for the public and private entities involved in projects related to regionalization of Romania to benefit from the database and specialized expertise offered by the project. Regarding the theoretical component, an innovative way to promote the project aims would be by means of scientific benchmarking of aspects of regionalization processes under the influence of new regionalism concept, taken in recent years by the European strategy of integration (Lombaerde, Baert, 2012) and a still has relatively low impact among Romanian research specialists. This new regionalism related methodological model, successfully applied in studies of Western (American and European) should be adapted to the specific requirement of our case (Mansfield, Milner, 1997), (Maatli, 1999), (Herrschel, Newman, 2002), (Telò, 2007). Recent contributions suggest a correlation of economic and financial analysis for regionalization policies regarding the identity of the historical and political traditions of various national states, in order to identify explanations for collective behaviours that can make it difficult or, conversely, can stimulate the process of regionalization (Breslin, Hughes, Phillips, Rosamond, 2004,10). Another innovative component of the research stems from the fact that regionalization should be understood as a complex response, on the one hand, the internationalization of markets and social division of labour, on the other hand, the political, economic and financial strategies of multinationals - EU policies of multinational companies, banking consortia, etc (Flemes, 2010, 15-29). 
In Romania, there does not exist sufficiently rich experience in interdependent and interdisciplinary research on topics such as those undertaken by this project and especially research products often remain confined to academia, without producing tangible benefits to business, the state, and the citizen. This perspective endured many political and ideological constraints, as well as the strict demarcation and teaching of fundamental areas of knowledge (history, economics, geography, sociology), which in part caused parallel discourses, and in other cases (demography) lack of tradition and interference from the communist regime, did not leave enough room for major development. However, experience in the Romanian research is a useful start, especially recent contributions. The need of justifying the national centralist-state, in democratic or totalitarian form, formed the foundation for the socio-economic, demographic and habitat policy perspective, which was mainly based in the tradition of historical writing. Romanian ,provinces," from a centrist point of view, were often viewed in the same way, from a teleological standpoint. There were, however, especially in the context of the search for a Romanian communal identity, further considerations beyond the Prut and the restructuring of post-December speech, saturated stereotypes, questions of „national project," a common destiny. Beyond the need to unify in 1859 , there were works that have attempted to quantify the costs incurred for Moldova (Ivănescu, Turliuc, 2001) and presenting classical works with inexorable process of union of Bessarabia and Bukovina and unification benefits on different levels administrative, fiscal, cultural, studies were soon published noting constraints, differences and sacrifices. Recent studies (Cuşco, 2011, 203-216) on the Romanian state modernization policy of the three southern districts of Bessarabia in the Russian Empire between 1857- 1878 and the reaction after 1878 , capture a "symbolic issue" between the two countries on several more levels: administrative, economic, demographic. Two state models are at odds with one another, one democratic and the other autocratic, and how to impose their respective vision of a region with economic and trade potential: control of the Lower Danube.

Recent economic and demographic studies have attempted current challenges, realizing interchangeable research products and assuming that productivity, economic efficiency or consumption are expressed by reference to the number of different categories of population size. Concerns in this regard cover both contexts and global perspectives and case studies. A volume published by Bogdan Murgescu is a very useful comparative analysis of socio-economic development on the Romanian and European level, based on the "obsession gaps." The author tries to explain how these development gaps were built and when these gaps accumulated while providing comparative analysis with other cases on the continent (Murgescu, 2010). The same general ledger and job falls Cornelia Mureşan, a summary of the demographic evolution in Romania, following the structure of the habitat and the urbanization process, sex and age structure of the population, legislation, using loglinear methods in regional chapters devoted to aspects of the demographic regime (Mureşan, 1999).

During the negotiations and discussions that took place in the period before accession to the EU were initiated, several research projects cover all the state of development of Romania in comparison with other EU member states. Through these projects, we remember the one coordinated by Valeriu IoanFranc, entitled Dezvoltarea durabilă a României în context European şi mondial (Sustainable Development of Romania in the European and global context), conducted under the auspices of the National Institute of Economic Research (Vasile, 2007) Among the initiatives that have sought to integrate the concerns of many researchers interested in social issues and dynamics of change in Romania, can be remembered the coordinated work volume (Iluş, Nistor, Rotariu, 2005). Such researches are focused more on current reality issues and seek to provide a projection of what will be happening in the near future and therefore do not concentrate on the historical aspect, and nor do they analyze the situation in the long term. The research series points is essential to this project from a comparative perspective, the topics and similar case-study tangents are coordinated in the volume by Ioan Bolovan (Bolovan, Paula, 2007) comprising an amount of studies focused on the experience of Transylvania, trying to provide a detached perspective of classical key of the national historiography that treat in many cases, the problems related to the demographic regime of the area in a passionate and ethnocentric way. The work captures demographic change occurring amid world wars, the refugee problem in 1940, returns, and case studies. Marinela Istrate provided an applied study of human geography, examining the role of cities in economic development of Moldova, the role of physical distances and a constraints framework played in shaping the urban settlement network, and how the 
centrality determines the characteristics of spatial mobility of population and the development of cities (Istrate, 2008). The two volumes (Jinga, Soare, Doboş, Roman, 2010) deals with a sensitive topic, but important in the economy of the project pronatalist's development under Ceauşescu (1966-1989), following its effects and impact on the population and it relates to similar phenomena in other countries in the communist camp, concluding that Romania has applied the most restrictive legislation on voluntary interruption of pregnancy.

Ethno-religious dimension is as challenging and it not be excluded from the sphere of interest of this research. By 1878, between the two world wars and during the communist state report, ethnic minorities have always been formally negotiated with around the policies adopted by the government and the Romanian parliament, and pragmatically at the community level, with local decision-makers. But although the dominant thinking of the Romanian state laws relating to minorities was, until World War II, the acceptance of international provisions, policies unification, centralization and politicoinstitutional homogenization and economic territories, in 1918 tense situations with minority ethnic dialogue was soon feigned. After 1945, inspired by the practice of the Soviet Union, the communist state under all ideological imperatives, revised its policy towards minorities, creating a new body composed of social classes that transcend ethnic and linguistic borders. Abolishing racial laws adopted after 1938 and building official atheism, in an attempt to reduce the importance of the religious factor in identifying the group, the new ,elite” aims to incorporate minority communities in the social and political system of the Communist bill. There was, therefore, a formal integration, symbolic, beyond the means of setting administrative policy towards minorities, but these measures were often perceived as being imposed, and not agreed to, and led to resistance and institutional reluctance, factors promoted by the central and local power in relation to "the others" (Hebrew, Roma, Russians, Poles, Ukrainians, Bulgarians) tacit exclusion policies led to the closure of the key institutions of the Romanian state for the minority. There is an amount of more recent work published volumes of documents and state policies towards Virgil Pană (Pană, 1996), Levente Salat (Salat, 2008), Monica Vlad (Vlad, 2008), Irina Livezeanu (Livezeanu, 1998), Stefano Bottoni (Bottoni, 2010) and serial collective volumes (five in number) coordinated by Sorin Radu, Vasile Ciobanu (Ciobanu, Radu, 2006-2011) and research institutes focused specifically on minority issues as the Institute for Research on National Minorities in Cluj Napoca. Their philosophy is based on organizing and analyzing state policy Romanization of cities and industrialization, made by liberals in the interwar period. Elements of the debate focuses on the economic, administrative and cultural Romanian authorities, objectives seen as necessary Romanian affirmation element in the new provinces, but also some concepts that circumscribe state policy: educational and administrative unification of Romania as a territorial form of integration and homogenization, but not the integration of minorities, racial resorts of state action, the trend of assimilation by the majority of other Romanians.

\section{Conclusions}

In conclusion, the objectives of our research are focused on two fundamental aspects - knowledge and communication. The research component is of course primarily dedicated to the subject of knowledge, perspective and interdisciplinary analytical priority, which is subordinated to the collection and processing of a demographic, economic, cultural reference period. The objective is to identify specific features of Moldova, in terms of historical, demographic, and economic and responses / reactions to public policy in different historical stages. Setting these goals assumes the existence of differences in development between Moldova and other historical regions of the country, but also between different sub-regions of Moldova. The public policies of the Romanian regimes between 1859 and 2012 have managed successfully to mitigate these differences. On the contrary, the gap increased and labor migration from Moldova, a national domestic phenomenon before 1989, turned to the West in the context of de-industrialization of the country and EU integration. Component of research / knowledge has a fundamental aim to identify rational, substantiated and reliable answers, resulting in a complex analysis with a solid interdisciplinary and comparative component. To achieve this objective, scientific challenges mainly focuses on the processing of data gathered from their investigation of historical research, and demographic and economic data to be classified and correlated based on a number of specialized criteria that require interdisciplinary efforts. Research in the project, in all its complexity, will lead to some solid conclusions on the human and material potential of Moldova, according to demographic and economic benchmarks correlated quantitatively, following their dynamics in time 
and space, opportunities for regional development and the specific cross-based characteristics of the region and collective behaviours, and vulnerability of the region, as they result from historical experience.

\section{Acknowledgement}

This work was supported by a grant of the Romanian National Authority for Scientific Research and Innovation, CNCS - UEFISCDI, project number PN-II-RU-TE-2014-4-1665.

\section{References}

Alexia, P., Fent, T., Barthel, W., Crespo-Cuaresma, J., Lindh, T., Malmberg, B., HalvarssonM. (2007), Study of The Relationship Between Demographic Change and Economic Growth in the EU. Research Report 32.

Bartholomae, F. W., Popescu, A. M. (2007), The Role of Regional Competition for Demography and Regional Disparities in Germany, Romanian Journal of Regional Science, 1 (1), 45-70.

Berindei, M, Dobrincu, D., Goşu, A. (2009), Istoria comunismului din România, I, Perioada Gheorghe Gheorghiu-Dej (19451965) [History of Communism in Romania, I, Gheorghe Gheorghiu-Dej Period 1945-1965], Bucuresti, Humanitas.

Bolovan, I., Paula, S. (2007), Mişcări de populaţie şi aspecte demografice în România în prima jumătate a secolului XX. Lucrările Conferinţei Internaţionale [Population Movements and Demographic Aspects in Romania in the First Half of the 20th Century. The works of the International Conference], Cluj Napoca, Presa Universitara Clujeana, 590.

Bonifazi, C., Crisci, M. (2013), Demography, Migration and the Economy at the Regional Level: Recent Evidence from Catalonia, Applied Spatial Analysis and Policy, 6 (3), 229-249.

Bottoni, S. (2010), Transilvania roșie. Comunismul român și problema națională 1944-1965 [Red Transylvania. Romanian Communism and the National Problem 1944-1965], Cluj Napoca, Kriterion, 344.

Breslin S., Hughes C. W., Phillips, N., Rosamond, B. (2004), New Regionalisme in the Global Political Economy. Theories and Cases, , London, Routledge, 257.

Ciobanu, V., Radu, S. (2006-2011), Partide politice şi minorităţi naţionale din România în secolul XX [Political Parties and National Minorities in Romania in the 20th century], Sibiu, Lucian Blaga University Publishing.

Cuscco, A. (2011), Problema Basarabiei de Sud în discursul imperial rus după 1878: viziuni ale alterităţii și transferuri instituţionale [South Bessarabian Problem in the Russian Imperial Discourse after 1878: Alternate Views and Institutional Transfers], Partide politice și minorităţi naţionale din România în secolul XX, VI, Sibiu, Lucian Blaga University Publishing, 203-216.

Flemes, D. (2010), Regional Leadership in the Global System, London, Ashgate Publishing.

Herrschel, T., Newman, P. (2002), Governance of Europe‘s City Regions, New York, Routledge.

Iluş, P., Nistor, L., Rotariu, T. (2005), România socială. Drumul schimbării şi al integrării europene [Social Romania. The Path of Change and European Integration], I-III, Cluj Napoca, Eikon.

Istrate, M. (2008), Relaţiile urban-rural în Moldova în perioada contemporană [Urban-Rural Relations in Moldova during the Contemporary Period], Iaşi, Alexandru Ioan Cuza University Publishing, 352.

Ivănescu, D., Turliuc, C. (2001), Vârstele Unirii: de la conştiinţa etnică la unitatea naţională [The Age of the Union: From Ethnic Consciousness to National Unity], Iaşi, A. D. Xenopol Fundation, 229.

Jinga, L. M., Soare, F. S., Doboş, C., Roman, C. (2010), Politica pronatalistă a regimului Ceauşescu. Instituţii şi practici [The Pronatalist Policy of the Ceausescu Regime. Institutions and Practices], Iaşi, Polirom.

Livezeanu, I. (1998), Cultură şi naţionalism în România Mare 1918-1930 [Culture and Nationalism in Romania 1918-1930], Bucureşti, Humanitas, 390.

Lombaerde, P., Baert, F. (2012), The United Nations and the Regions. Third World Report on Regional Integration, Brugge, Springer Netherlands, 272.

Maatli, W. (1999), The Logic of Regional Integration: Europe and Beyond, Cambridge, Cambridge University Press.

Mansfield, E., Milner. H. (1997), The Political Economy of Regionalism, New York, Columbia University Press, 337.

Mureşan, C. (1999), Evoluţia demografică a României. Tendinţe vechi, schimbări recente, perspective (1870- 2030) [Demographic Evolution of Romania. Old Trends, Recent Changes, Perspectives 1870-2030], Cluj Napoca, Presa Universitara Clujeana, 274.

Murgescu, B. (2010), România şi Europa: acumularea decalajelor economice (1500- 2010) [Romania and Europe: the accumulation of economic gaps 1500-2010], Iaşi, Polirom, 528.

Pană, V (1996), Minorităţile etnice din Transilvania între anii 1918-1940: drepturi şi privilegii [Ethnic Minorities in Transylvania Between 1918-1940: Rights and Privileges], Târgu Mureş, Tipomur Publishing, 311.

Popa, A. (2010), Fizionomii urbane şi structuri etno-sociale din Moldova. Bacăul în tranziţia de la târg la oraş (1864-1938) [Urban Physiognomies and Ethno-Social Structures in Moldova. Bacau in the Transition From the Fair to the City 18641938], Iaşi, Pim, 406.

Salat, L. (2008), Politici de integrare a minorităţilor naţionale din România: aspecte legale şi institutionale într-o perspectivă comparată [Policies for the Integration of National Minorities in Romania: Legal and Institutional Aspects in a Comparative Perspective], Cluj, ORDE, 272. 
Scholich, D., German Annual of Spatial Research and Policy 2007. Teritorial Cohesion, Heidelberg, New York, Springer Verlag.

Telò. M. (2007), European Union and New Regionalism, Ashgate Publishing, 406

Territorial Outlook by OECD (2001), Paris, 292.

Tivig, T., Frosch, K., Kühntopf S. (2008), Mapping Regional Demographic Change and Regional Demographic Location Risk in Europe Final Report, Berlin, Haus der Deutschen Wirtschaft, 108.

Vasile, V. (2007), Interdependenţe între dezvoltarea durabilă a României şi a ţărilor membre UE [Interdependencies Between the Sustainable Development of Romania and the EU Member Countries, Bucuresti, Expert Publishing. 